\title{
THE INFLUENCE OF TRUST AND INFORMATION QUALITY ON ONLINE PURCHASE DECISION IN THE SHOPEE APPLICATION (A CASE STUDY ON PT SRI BOGOR'S EMPLOYEE)
}

\author{
By \\ Esa Indra Mustika ${ }^{1}$ \& Antoni Ludfi Arifin ${ }^{2}$ \\ ${ }^{1,2}$ Business Administration Program Institute of Social Sciences and Management STIAMI Jakarta \\ Email: ${ }^{1}$ esaindra93@gmail.com \& ${ }^{2}$ ludfi@ stiami.ac.id
}

\begin{abstract}
Article Info
Article history:

Received May 8, 2021

Revised June 20, 2021

Accepted July 19, 2021

Keywords:

Trust

Quality Information

Purchase Decision

ABSTRACT

This study aims to determine how trust and information quality influence online purchasing decisions for Shopee application users. This research is a quantitative study with trust, information quality, and purchase decisions as variables. The population of this research was employees of PT SRI Bogor, who had at least used the Shopee application once. The sample used in this study consisted of 90 respondents who were taken using the accidental sampling technique. Data collection was carried out using questionnaires, in which each respondent was given 25 statements. The data were then analyzed using regression analysis techniques, classical assumption tests, and hypothesis testing. The results of this study indicate that: (1) Trust has a positive effect on purchasing decisions with a value of 28\%; (2) Quality of information has a positive effect on purchasing decisions with a value of $37.4 \%$; (3) Trust and quality of information simultaneously influence purchasing decisions with a value of $43.4 \%$, while the remaining $56.6 \%$ is influenced by other variables not examined.
\end{abstract}

This is an open access article under the CC BY-SA license.

\author{
Corresponding Author: \\ Esa Indra Mustika \\ Business Administration Program Institute of Social Sciences and Management STIAMI Jakarta \\ Email: esaindra93@gmail.com
}

\section{INTRODUCTION}

In recent years, technological development is more sophisticated and continues to be more advanced than past several years. The development can be observed in various aspects starting from transportation, communication, trade, and et cetera. Hence, the people's lifestyle also changes and shifts from conventional to automatic because of technological development. The most conspicuous from the advancement is a gadget and the tendency of people to do activities in cyberspace such as buying through the internet or online shopping. Parallel with technological development, internet development also evolves rapidly, which very helpful for ordinary people in online shopping. Observing the statistics data in APJII sites (Asosiasi Penyedia Jasa Internet Indonesia) reveals that the internet user keeps on growing each year in Indonesia. A survey conducted by APJII in 2018 discloses Indonesian internet users reach up to 171,17 million users or $64,8 \%$ of the country's total population, and the number increased $10,12 \%$ from the previous year in 2017. With the increase of internet users yearly in Indonesia, it can encourage online shopping users' enormous potential, and thus, plenty of e-commerces are established in this country; one of them is Shopee. Shopee is one of the e-commerce existed in Indonesia. It's headquarter in Singapore, the company was established in 2015, and the company has a powerful influence to make online shopping wider in Indonesia. Based on the above 
description, the researchers are motivated to conduct research entitled "The Influence of Trust and Information Quality on Online Purchase Decision in the Shopee Application (A Study Case on PT SRI Bogor's Employee).

Based on the background explained above, the formulation of problems on this research are:

1. How much the influence of trust on online purchasing decisions?

2. How much the influence of qualified information on online purchasing decisions?

3. How much influence of trust and quality of information on online purchasing decisions?

Research Objective:

1. To find out the influence of trust on online purchasing decisions?

2. To find out the influence of qualified information on online purchasing decisions?

3. To find out the influence of trust and quality of information on online purchasing decisions?

\section{Theoretical Foundation}

1) Administration

According to Anggara (2012: 1), "Administration is a process of organizing resources so that people can properly and correctly do the workload in whatever level of organization can." According to Fahmi (2015: 1), "Administration is a relationship-building which arranged systematically forming an inter-cooperative to each other network to support the establishment of arranged working mechanism and to achieve the desired objectives." According to Trisna in Daryanto (2011: 7), "Administration is an overall process of organizing in a cooperative effort of two people or more rationally to achieve predetermined goals efficiently."

2) Business

According to Sukirno (2010: 20), business is an activity to obtain profit, everyone or individual or group conduct business activity to gain profit to meet their life necessity. No one wants to do business to gain losses. According to Madura (2010: 2), people create a good and service product for customers. Every business conducts a transaction with other people. Those people bear the consequences because of the business, and they are crossfunctional cooperation within the business to emphasize the need for managers from different functional areas to maximize profits in achieving common goals. Business administration is the management that classifies and explains every work stage in a business presented in clear and firm and planned actions.

3) Purchase decision

According to Schiffman and Kanuk (Sudaryono, 2014: 210), "the decision from selecting two or more alternative options. A consumer who wants to choose must have an alternative option. A decision without an option is called the "Hobson option." Setiadi (Sangadji and Sopiah, 2013: 121) reveals that "The essence of consumer decision making is an integration process that combines knowledge to evaluate two or more alternative behaviors and choose one of them. The integration process result is a choice that is presented cognitively as a desire to behave". Furthermore, Suharno (2010: 96) also explains that "purchasing decision is when the buyer has determined their product and conduct the purchase to consume the product."

4) Trust

According to Sumarwan (Sangadji and Sopiah, 2013: 201), trust is a strength, that a product must have a specific attribute. He often calls a trust as the object-attribute linkage that is consumer trust on the possibility of a relation between an object with its relevant attribute". Rotter (Widokarti and Priansa, 2019: 73) states that "trust as a hope which holds by an individual or a group when the words, promises, oral or written statement of an individual or other group can be created." In addition to the above description, Kotler and Keller (Bob Sabran, 2012: 225) state that "trust is the willingness of a company to count on their business partner. The trust depends on numerous interpersonal and inter-organizational factors, such as company competition, integrity, honesty, and fairness."

5) Information Quality

According to Leppeveld et al. (Hartono, 2013: 17), information quality must have eight aspects:

a) Relevance, the information provided or displayed is used by users. Hence, a piece of high-value information is the one that is relevant to the requirements, namely for what people will use the information.

b) Completeness and Vastness, Information will increasingly high value if presented in whole with its broad scope. A piece of partial information, or unsystematic arranged, surely will not provide many effects. Moreover, if the information only covers a small area of an issue.

c) Truth, its validity determines the truth of information or can it be proved. Information comes from data and facts. A piece of high-value information is the one that actually comes from facts, not an opinion or illusion.

d) Measurable, Information comes from data or the results of measurements and the recording of facts. So, highvalue information is information that, if traced back to the data, the people can measure the data conforming to the facts. 
International Journal of Social Science (IJSS)

Vol.1 No.2 August 2021, pp: 37-42

ISSN: ISSN: 2798-3463 (Printed) | 2798-4079 (Online)

DOI: https://doi.org/10.53625/ijss.v1i2.134

e) Accuracy, Information comes from data or measurement results and recording of the facts. Thus, accuracy in measuring and recording facts will determine the accuracy of the data and the value of the information generated.

f) Clarity, user can present information in various forms of text, tables, graphs, charts, and others. However, whatever the form chosen on the web, the critical thing simplifies the user to understand its meaning. Therefore, in addition to the presentation form, it must be correct. The user's ability to understand it must also be considered.

g) Flexibility, good information is the one that can be easy to change its presentation conforming to the situation and requirement at hand.

h) Punctuality, good information presented at the right time when it is needed. A late coming Information will become a worthless piece of information. (For instance, in decision making).

Meanwhile, according to Sutabri (2012: 33), the quality of information depends on three aspects, e.g.,

a) Accurate, Information must be free from errors and misleading. Accurate also means that information must reflect its intention.

b) Timelines, information coming to the receiver must not be late. Obsolete information is a worthless piece of information because it is a foundation in decision making in which if the decision is late, it will make a fatal impact on the organization.

c) Relevance, the information is helpful for the users. The relevance of the information for every person is different. For example, conveying information about the causes of damage in production machines to the company accountant is undoubtedly less relevant. It will be more relevant if it is addressed to the company's technical experts and vice versa.

McLeod (Susanto, 2013: 38) conveys that a piece of qualified information must have the following features:

a) Accurate means that information must reflect the actual condition. The testing accuracy will be done by two people or more. If the test produces the same result, the data will be stated accurately.

b) Punctuality means the information must exist when needed, not tomorrow or a few hours from now.

c) Relevant means the information given must correspond to the requirements of the individual at every level within an organization.

d) Complete means that information must be given in whole or complete.

\section{Theoretical Framework}

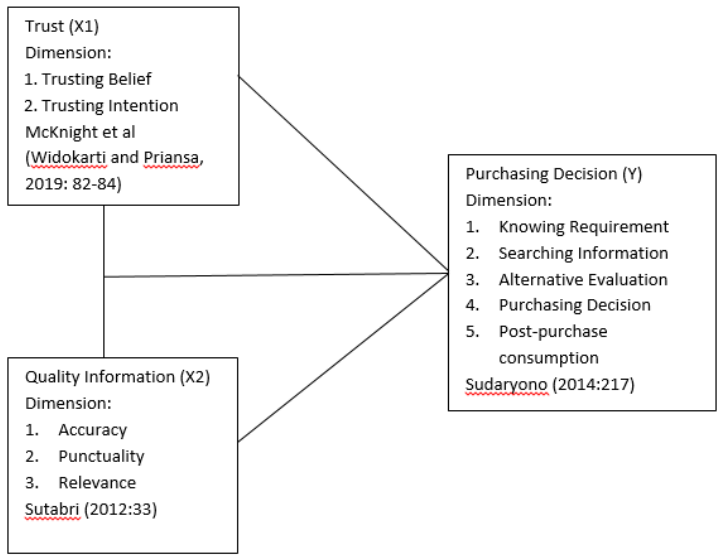

\section{RESEARCH METHODS}

Research Type

In this study, the researchers apply a quantitative approach because it wants to find the relation between trust (X1) and information quality (X2) toward purchase decision (Y). The research method used is a survey method. The primary data in this research is obtained in the field research by spreading questionnaires to the respondent.

\section{Population and Sample}

The population in this study is the employees in PT SRI Bogor, particularly the plant one tire assembly section. It consisted of 300 employees who had used/transacted using Shopee application by minimal one time, and sample in this research using Newman theory (Silaen, 2018:90) that is using 30\% of the total population if the population is under 1000 , the sample used in this research is $30 \%$ x $300=90$ people respondent.

Sample Collection Techniques 
The type of technique used is Accidental Sampling, which is a sampling technique based on chance, that is, anyone who happens to meet a researcher who has used the Shopee application at least once.

\section{Data Analysis Techniques}

In this study, the researchers apply SPSS version 24 software as the data processor for the questionnaire. The results of processing questionnaire data through SPSS version 24.0 software will produce a frequency distribution and percentage of questions for each indicator/statement.

1) Validity test

The validity test is applied to determine the level of obstacle or error from the questionnaire spread by the researchers. A valid instrument means that the instrument can be used to obtain data (measure) what should be measured.

2) Reliability test

The reliability test is the tool to measure a questionnaire that indicates a variable or a construct (Ghozali, 2011:

47). A questionnaire is reliable or reasonable if the respondent's answer to the questions is stable or consistent from time to time.

3) Classic Assumption test

a) Normality Test

It is used to test whether the residual value generated from regression is distributed equally normal or not.

b) Multicollinearity Test

The multicollinearity test aims to find out the perfect or near-perfect correlation between variables on the regression model. A good regression model should not occur correlation between variables.

c) Heteroscedasticity Test

d) The heteroscedasticity test aims to test whether the regression model created equality of variance from the residual of one observation to the other observations. If the residual variance from one observation to the other observation is fixed, it is called homoscedasticity, and if it is different, it is called heteroskedasticity.

4) Statistics Test

a) Regression Analysis test

The simple regression analysis was used to determine each first independent variable, e.g., trust (X1) and information quality (X2) toward the dependent variable purchase decision (Y). Two-predictors regression analysis was applied to find out the influence of independent variable simultaneously toward dependent variable.

b) Correlation Test (R)

According to Silaen and Widiyono (2013: 222), "Correlation analysis using statistics test was intended to measure the degree of correlation from two different variables, independent and dependent variables." Regression analysis was used to find out the relation between trust, information quality, and purchasing decisions.

c) T-test

The T-test was used to test whether independent variables significantly influence dependent variables by comparing to $\mathrm{T}$ table with $\mathrm{T}$ count obtained based on $5 \%(\mathrm{a}=0.05)$ significance level.

d) $F$ test

The $\mathrm{F}$ test was used to find out the significant influence of independent variables simultaneously toward independent variables.

e) Coefficient of Determination Analysis (R2)

This coefficient of determination explains the influence of the variable $\mathrm{X}$ percentage on the fluctuations in the variable Y value, while the remaining difference from $100 \%$ is the influence caused by other factors not examined.

\section{RESULTS AND ANALYSIS}

Validity Test

The validity test from the three variables concludes that the t-count value on all items used was more than 0.213 value or more significant than the t-table value. Thus, all items statements in all variables are valid.

\section{1) Reliability Test}

The deduction of reliability test on the three variables, e.g., trust (X1), information quality (X2), and purchasing decision (Y), the result of Cronbach's alpha calculation is $>0.60$. Based on this, it can be deduced that all items in all variables are reliable.

2) Classic Assumption Test

\section{1) Normality Test}


International Journal of Social Science (IJSS)

Vol.1 No.2 August 2021, pp: 37-42

ISSN: ISSN: 2798-3463 (Printed) | 2798-4079 (Online)

DOI: https://doi.org/10.53625/ijss.v1i2.134

The normality test result shows a significant value on the unstandardized residual of all dependent and independent variables that will be tested is as much as 0.200 ; it is more significant than the alpha 0.05 value, meaning that all residual variables are distributed normally.

2) Multikolonierity Test

The multicollinearity test shows the Tolerance value for trust variable (X1) and information quality (X2) is 0.727 ; it is greater than 0.10 . Meanwhile, VIF value for trust (X1) and information quality (X2) variable is $1,375<10,00$. It can be concluded that multicollinearity did not occur in the regression model.

3) Heteroskedesity Test

The heteroskedasticity test shows that significance (sig.) for trust (X1) is 0.95 . Meanwhile, significance value (sig.) for information quality variable (X2) is 0,548 . Because significance value (sig.) Both variables above are more significant than 0.05 , and it can be deduced that it was never heteroskedastic.

4) Statistic Test

\section{a) Simple Linear Regression}

The research result shows that the trust variable (X1) positively influences toward purchase decision variable $(\mathrm{Y})$, and the Information quality variable (X2) also positively influences on purchasing decision variable (Y).

b) Two-predictors Linear Regression

The research result shows coefficient trust value by 0.296 , which positively influences the purchasing decision, and information quality also shows coefficient value by 0.328 , which positively influences purchasing decision.

c) Coefficient Determination

The research result shows a coefficient determination $\left(\mathrm{R}^{2}\right)$ value as much as 0.434 , which means trust variable (X1) and information quality variable (X2) influence purchasing decisions as much as $0.434 \times 100 \%=43.4 \%$; meanwhile, the rest of $56.6 \%$ was influenced by other variables.

d) T-test (partial)

This research result shows that for the trust variable, the T-count $5.848>\mathrm{T}$ table of 1.662 , it can be concluded that the trust variable influences partially toward purchasing decision. Meanwhile, for the information quality variable is that the t-count $7.245>\mathrm{t}$-table 1.662 , it can be concluded that information quality influences partially toward purchasing decision.

e) $\mathbf{F}$ test (simultaneous)

The research result shows that $\mathrm{F}$ count $33.375>\mathrm{F}$ table 3.10. It can be concluded that trust and information quality variables simultaneously influence purchasing decisions.

\section{CONCLUSION}

The research results on trust and information quality toward online purchasing decisions on the Shopee application (a case study on PT Sri Bogor's employees), namely:

1. There is a positive and significant effect of Trust on Online Purchase Decisions in the Shopee Application on PT SRI Bogor's Employees stated that the correlation effect is 0.529 , and the influence of determination is $28 \%$.

2. There is a positive and significant influence on the information quality toward online purchasing decisions on the Shopee application. For PT SRI Bogor's employee has accepted the correlation effect by 0.611 , and the influence of determination is $37.4 \%$.

3. There is a positive and significant influence of Trust and Information Quality Simultaneously on Online Purchase Decisions in the Shopee Application by PT SRI Bogor's employees, it is stated accepted the correlation effect amount of 0.659 and the influence of determination is as much as $43.4 \%$.

Suggestion

Suggestion to e-commerce Shopee company, it is better to increase the security in the transaction and ensure again that the seller meets the applicable terms and conditions before selling products to users. Furthermore, the company provides up-to-date, complete, transparent, and exciting information about products, prices, locations, and promotions in the Shopee application. The user's trust level increases and the Shopee application's information quality becomes easy for users to make purchasing decisions.

\section{REFERENCES}

[1] Anggara, 2012. Ilmu Administarasi Negara Kajian Konsep, Teori dan Fakta dalam Upaya Menciptakan Good Governance. Bandung: PustakaSetia

[2] Daryanto. 2011. Sari Kuliah Manajemen Pemasaran. Bandung: PT Sarana Tutorial Nurani Sejahtera.

[3] Fahmi, Irham. 2015. Pengantar Ilmu Administrasi Bisnis. Bandung: Alfabeta. 
[4] Ghozali, Imam. 2011. Aplikasi Analisis Multivariate dengan Program SPSS19. Semarang: Badan Penerbit Universitas Dipenogoro

[5] Hartono, Bambang. 2013. Sistem Informasi Manajemen Berbasis Komputer. Jakarta: Rineka Cipta

[6] Kotler, Phillip dan Gary Armstrong. (diterjemahkan oleh Bob Sabran). 2016. Prinsip-prinsip Pemasaran. Jakarta: Erlangga.

[7] Madura, Jeff, 2010. Financial Institution and Markets: Ninth Edition. Canada: South-Western Cengange Learning. (Thompson southwestern)

[8] Peppers, Don and Martha Rogers, 2004. Managing Customer Relationships: A Strategic Framework, New Jersey: John Wiley \& Sons, Inc.

[9] Priyastama, Romie. 2017. Buku Sakti Kuasai SPSS. Bantul: PT. Anak Hebat Indonesia.

[10] Sangadji, Sopiah, 2013. Perilaku Konsumen. Yogyakarta: C.V Andi Offset

[11] Silaen. 2018. Metodologi Penelitian Sosial untuk Penulisan Skripsi dan Tesis edisi revisi. Jakarta: Penerbit In Media.

[12] Silaen, Widiyono. 2013. Metodologi Penelitian Sosial Untuk Penulisan Skripsi dan Tesis. Jakarta: PenerbitIn Media.

[13] Silalahi, Ulber. 2015. Metode Penelitian Sosial Kuantitatif. Bandung: PT. Refika Aditama.

[14] Sudaryono, 2014. Perilaku Konsumen Dalam Perspektif Pemasaran. Jakarta: Lentra Ilmu Cendiaka

[15] Sugiyono. 2011. Metode Penelitian Kuantitatif, Kualitatif dan Kombinasi (Mixed Methods). Bandung: Alfabeta

[16] 2010. Metode Penelitian Kuantitatif, Kualitatif dan Kombinasi (Mixed Methods). Bandung: Alfabeta.

[17] Sugiyono. 2012. Metode Penelitian Manajemen. Penerbit Alfabeta

[18] Suharno dan Yudi Sutarso. 2010. Marketing in Practice. Yogyakarta: Graha Ilmu.

[19] Sukirno, Sadono, 2010. Mikro Teori Pengantar. Jakarta: PT Raja Grafindo Persada.

[20] Susanto, Azhar. 2013. Sistem Informasi Akuntansi. Bandung: Lingga Jaya

[21] Sutabri, Tata. 2012. Analisis Sistem Informasi. Yogyakarta: Andi

[22] Widokarti, Priansa. 2019. Konsumen, Pemasaran, dan Komunikasi Kontemporer. Bandung: CV Pustaka Setia

[23] Yunus. 2019. Digital Branding Teori dan Praktik. Bandung: Simbiosa Rekatama Media

[24] Iwan Sidharta dan Boy Suzanto. 2015. Pengaruh kepuasan Transaksi Online Shopping dan Kepercayaan Konsumen Terhadap Sikap Serta Perilaku Konsumen Pada E-commerce. Jurnal Computech \& Bisnis, Vol.9, No.1 Juni 2015.

[25] Rosian Anwar dan Wijaya Adidarma. 2016. Pengaruh Kepercayaan dan Risiko Pada Minat Beli Belanja Online. Jurnal Manajemen dan Bisnis Sriwijaya, Vol.14, No.2 juni 2016.

[26] Yugi Setyarko. 2016. Analisis Persepsi Harga, Promosi, Kualitas Layanan, dan Kemudahan Penggunaan Terhadap Keputusan Pembelian Produk Secara Online. Jurnal Ekonomika dan Manajemen, Vol.5 no.2 Oktober 2016.

[27] Sri Nawangsari dan Yelsi Karmayanti. 2018. Pengaruh Kepercayaan, Kemudahan, dan Kualitas Informasi Terhadap Keputusan Pembelian Melalui Media Sosial Instagram. Konferensi Nasional Sistem Informasi 2018 STMIK Atma Luhur Pangkalpinang, 8-9 Maret 2018.

[28] Denni Ardyanto dan Heru Susilo Riyadi. 2015. Pengaruh Kemudahan dan Kepercayaan Menggunakan Ecommerce Terhadap Keputusan Pembelian Online. Jurnal Administrasi Bisnis, Vol.22, No.1 Mei 2015

[29] Yoon C Cho. 2015. Exploring Factors That Affect Usefulness, Ease of Use, Trust, And Purchase Intention in The Online Environment. Internationa of Management \& Information System - First Quarter 2015, Vol.19 No.1.

[30] www.apjii.or.id 